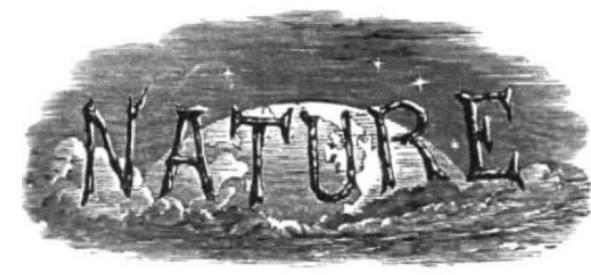

SATURDAY, SEPTEMBER 2I, I929.
PAGE

Colonial Development and the Scientific Worker Epidemic Diseases. By A. S. M.

The Teaching of Science. By Dr. E. J. Holmyard Minerals and Animal Nutrition. By Prof. T. B. Wood, F.R.S.

The Low Veld. By J. S. G.

Our Bookshelf

Letters to the Editor:

Glasses Transparent to Ultra-violet Radiation. -A. R. Wood and M. N. Leathwood

Turbulence in the Sun's Atmosphere.-...W. H. McCrea

A Habit of the Common Periwinkle (Littorina littorea Linn.).--D. P. Wilson .

The Nitrogen Afterglow.-Dr. E. J. B. Willey

Natural Selection.-J. B. S. Haldane

Rate of Dissociation of Nitrogen Tetroxide.Prof. A. R. Olson and C. E. Teeter, Jr. .

A Function of the Adrenal Cortex.-Prof. Swale Vincent and J. H. Thompson .

A Crystalline Tripeptid from Living Cells.-Sir F. Gowland Hopkins, F.R.S. . . . .

Zoological Nomenclature.-Dr. C. W. Stiles

The Enclosure of the Zuider Zee. By Dr. Brysson Cunningham

Botanical Records of the Rocks : with Special Reference to the Early Glossopteris Flora. By Prof. A. C. Seward, F.R.S.

Low Frequency Sound Waves and the Upper Atmosphere. By E. H. Gowan . . . . . Obituary :

Dr. W. G. Duffield. By H. F. N. . . . 454

News and Views . . . . . . . . . 455

Our Astronomical Column $\quad . \quad$. $\quad . \quad$. $\quad . \quad$. 459

Research Items . $. \quad . \quad . \quad . \quad . \quad .460$

The Treatment of Slash in Chir Pine Forests in the

North-west Himalaya . . . . . .

Prehistoric Society of East Anglia . . . 464

Scientific Utilisation of Coal. By H. J. H. . . 464

Ventilation . . . . . . . . 465

Calendar of Patent Records . . . . . . . $\quad$. 465

Societies and Academies . $\quad . \quad$. $\quad . \quad$. $\quad . \quad$. $\quad .466$

Official Publications Received . . . . . . . 467

Diary of Societies . $\quad . \quad$. $\quad . \quad$. $\quad . \quad$. 468

Editorial and Publishing Offices:

MACMILLAN \& CO., LTD.,

ST. MARTIN'S STREET, LONDON, W.C. 2.

Editorial communications should be addressed to the Editor. Advertisements and business letters to the Publishers.

Telephone Number: GERRARD 8830.

Telegraphic Address: PHUSIS, WESTRAND, LONDON.

\section{Colonial Development and the Scientific} Worker.

NYBODY who troubles to read the official A reports of the debates which took place during the last session of Parliament would be struck by the continual references made to the importance of scientific research. The subjects upon which the debates centred, for example, industrial development in Great Britain, colonial development, and others which it is hoped will provide a solution to our unemployment problem, are not new. The principal protagonists in Parliament of scientific research have not changed, although their arguments have gained point and emphasis because scientific workers in recent years have proved themselves by the results they have obtained over a large field of endeavour. What is novel is the hold which science now has upon the imagination of a large number of rank and file members of both Houses of Parliament. Their critical interest in scientific research is one of the happiest auguries for the future.

When Mr. Thomas introduced the Colonial Development Bill, he occasioned some surprise by including in its clauses one providing for the encouragement of scientific research. It has been assumed for some time past that all schemes for the prosecution of scientific research in the colonial empire, other than those promoted by the colonies themselves, were covered by the activities of the Empire Marketing Board, which it will be remembered was set up in 1926 as a direct result of the recommendations of the Imperial Economic Committee. Some members feared that the introduction of this clause might lead to unnecessary overlapping between the Empire Marketing Board and the Committee which Mr. Thomas promised would be appointed to deal with the allocation of the funds provided by this new Bill. They expressed the fear also that since the expenditure under the new Bill was to be controlled by an annual vote of Parliament, and that any unexpended balances in one year could not be carried over to the next, that Mr. Thomas had been unduly influenced by those critics, including the Treasury, of the Empire Marketing Board who are still unconvinced of the desirability of providing funds for statutory bodies to enable them to consider long-range schemes in connexion with research and technical development. That their fears were justified was evident from Mr. Thomas' subsequent declaration that he proposed to bring the Empire Marketing Board funds under statutory control, a distinct reversal

No. 3125, VoL. 124] 
of the method of administration of the funds at its disposal.

Lest the objections of Mr. Amery, Mr. OrmsbyGore, Major Church, and others interested in the application of science to colonial development should be considered trivial by scientific workers unfamiliar with the machinery of State, it should be explained that a Parliamentary grant to a body for specified purposes differs greatly from a statutory grant. The former gives comparative freedom to those appointed to administer the grant to apply the funds at its disposal without constant reference to and sanction by the Treasury : a statutory grant involves Treasury control over every item of expenditure, and Treasury sanction of every scheme put forward by those theoretically charged with the administration of the funds annually voted by Parliament. Whatever may be the merits of this form of administration for most forms of State expenditure, it is not calculated to assist those responsible for the initiation of research and development schemes. Such schemes may involve financial commitments over a term of years, not infrequently they will not come to maturity for years, and the administering body must take these factors into account. It is obviously best able to do so if its unexpended balances at the end of a financial year can be carried over from one year to the next, instead of being returned to the Sinking Fund.

The fact that scientific workers as a whole registered no protest against what can only be considered as a retrograde act on the part of Mr. Thomas, is merely indicative of their apathetic lack of interest in the assembly which has so great an influence on their work. To this same cause can be attributed the absence of any scientific worker on the committee appointed by Mr. Thomas to administer the Colonial Development Fund, in spite of his declaration that this committee would be entrusted with the task of co-ordinating its own programme of research with that of the Empire Marketing Board. Were the debates in Parliament not fully reported, had scientific workers not been given so striking a lead by Mr. Amery in his speech on July 12 when he pleaded eloquently that the committee which Mr. Thomas proposed to appoint should not consist purely of eminent business men with a business chairman, their indifference to measures calculated to have a tremendous effect on the future of scientific research might be excused. Were the contributions already made by science to civilisation in general and colonial development in particular of small account, or were those scientific workers in the colonies adequately rewarded and given other forms of recognition commensurate with those of other professional workers, there might be some justification for their attitude of aloofness. But in present circumstances there is neither justification nor excuse for it. They may dislike and distrust politicians as a class, but they must realise that in our politicians is vested the power to vote the moneys necessary for all public services at home and in the colonial empire. Politicians reflect public opinion. They are most susceptible to the influence of the better-educated sections of the public, provided those sections are vocal.

In recent years successive Governments have appointed committees to deal with an extensive variety of subjects upon which scientific workers could speak with authority. There was a most important committee on industry and trade appointed in 1924 by Mr. Sidney Webb (now Lord Passfield). Its deliberations were spread over years. Atvariousstages of its inquiries it consulted scientific experts. But no scientific worker was appointed to the committee, which means that no scientific worker was able to exercise any great influence on the committee's final recommendations. The same thing is true of the last Royal Commission on the Coal Industry. This Commission was assisted by scientific assessors, but science was not officially represented on the main body. Science, it might be assumed, might have had some real contribution to make to the recent deliberations of the Cotton Arbitration Committee. But its representatives, and there are many actively engaged in the industry, do not appear to have been consulted. Apart from Government committees there is another field which might reasonably be expected to engage the attention of scientific workers. For nearly two years past a committee has been sitting composed of representative employers, p.g. Lord Melchett, Lord Ashfield, Sir Robert Hadfield, and representatives of the Trade Unions. Had scientific workers as a body asked to be represented at this industrial conference, it seems reasonable to assume that they would have been welcomed. No such approach has been made.

It remains to be seen whether scientific workers will avail themselves of the opportunity to take a more active part in Imperial affairs which is afforded them by the recent formation of a Parliamentary Science Committee. This committee, which already numbers more than seventy members of the House of Commons, has been formed for the purpose of discussing the bearing of science on politics. Such matters as the wilful or unintentional omission of representatives of science from the Colonial Development Committee would come within its scope. Further, the Parliamentary Science Committee, being non-party, would probably be the best venue in which preliminary discussions could take place on the scope of scientific research as applied to the social as well as the economic development of our tropical Empire.

No. 3125 , VoL. 124] 